\title{
The genome and its role in ENT
}

This week the British Prime Minister, David Cameron, announced a $£ 300$ million funding boost to genetic research. This initiative increases investment in a project to map 100000 complete genetic DNA code sequences. The research will include exploration of the genomes of 75000 cancer patients and their relatives to look for variations in genetic codes that can predispose to disease.

Genetic research has much potential in the investigation of diseases of the head and neck. Articles published in this journal have explored this potential. Tissue engineering ${ }^{1}$ and tissue banking ${ }^{2}$ are key techniques used to maximise the utility of genetic research. Tissue banking is particularly important as it allows genetic material to be logged and stored for future research. In this way, biobanking will help identify biomarkers, enabling disease prediction and prevention. Most popular accounts of genetic research in the press naturally focus on DNA as the main subject of attention. The importance of RNA has, however, also been highlighted. A recent article in our Australian Supplement reviewed the importance of microRNA in head and neck cancer. ${ }^{3}$ MicroRNAs are small noncoding RNAs that are integral to the regulation of gene expression and which play a part in carcinogenesis. For example, high levels of miR-21 expression in head and neck cancer have been found to be associated with decreased five-year survival. In an article published by Shen and colleagues, the expression and functional effects, and related molecular mechanisms, of microRNA-519a in laryngeal squamous carcinoma were investigated. ${ }^{4}$ This microRNA may function as a tumour suppressor by inhibiting HuR expression.

It is to be expected that most advances in genetics in our field of medicine will relate to head and neck cancer. This is a disease that continues to have a poor prognosis for many patients, with available treatments having substantial morbidity. Genetic research offers the prospect of predicting which patients are more at risk of developing head and neck cancer. ${ }^{5,6}$ In addition, novel techniques, such as the detection of circulating tumour cells, enable investigation of the possibility of using such markers as diagnostic and therapeutic indicators in head and neck squamous carcinoma. Although head and neck cancer attracts most genetic attention, it should not be forgotten that genetics play a major part in the science of congenital deafness, with over 20 genes for non-syndromic autosomal recessive deafness being well characterised. In particular, mutations in the connexin 26 and 30 genes, and their effect on cochlear physiology, are important in congenital deafness. ${ }^{8}$

Developments in genetic research will offer great hope for many of our patients. We should not forget, however, that for the huge numbers of people suffering from disease and living in poverty, the prospect of this type of research helping them will seem light years away.

\section{ROBIN YOUNGS EDWARD FISHER Senior Editors}

\section{References}

1 Sivayoham E, Saunders R, Derby B, Woolford T. Current concepts and advances in the application of tissue engineering in otorhinolaryngology and head and neck surgery. J Laryngol Otol 2013;127:114-20

2 Warner E, Birchall M, Lowdell MW. Tissue banking in ENT: challenges and methods. J Laryngol Otol 2013;127:630-7

3 Gunawardena I, Fitzgerald J, Morley A, Hussey DJ, Woods CM, Carney AS. Micro-ribonucleic acids in head and neck cancer: an introduction. J Laryngol Otol 2013;127(suppl 2):S2-7

4 Shen Z, Zhan G, Deng H, Ren Y, Ye D, Xiao B et al. MicroRNA519 a demonstrates significant tumour suppressive activity in laryngeal squamous cells by targeting anti-carcinoma $\mathrm{HuR}$ gene. J Laryngol Otol 2013;127:1194-202

5 Aynali G, Doğan M, Sütcü R, Yüksel O, Yariktaş M, Unal F et al. Polymorphic variants of MnSOD Val16Ala, CAT-262 C $<\mathrm{T}$ and GPx1 Pro198Leu genotypes and the risk of laryngeal cancer in a smoking population. J Laryngol Otol 2013;127:997-1000

6 Boy Metin Z, Aydin S, Unur M, Cakmakoglu B, Toptas B, Hafiz G. Oral squamous cell carcinoma and serum paraoxonase 1. J Laryngol Otol 2013;127:1208-13

7 He S, Li P, He S, Long T, Zhang N, Fang J et al. Detection of circulating tumour cells with the CellSearch system in patients with advanced-stage head and neck cancer: preliminary results. J Laryngol Otol 2013;127:788-93

8 Tarkan Ö, Sari P, Demirhan O, Kiroğlu M, Tuncer Ü, Sürmelioğlu Ö. Connexin 26 and 30 mutations in paediatric patients with congenital, non-syndromic hearing loss treated with cochlear implantation in Mediterranean Turkey. J Laryngol Otol 2013;127:33-7 